\title{
Notes on liberal (arts) education discourse
}

\section{KEYWORDS}

liberal arts, liberal arts and sciences, liberal education, critical discourse analysis, philosophy of education, general education, neoliberalism

\begin{abstract}
Kontowski Daniel, Notes on liberal (arts) education discourse. Kultura - Społeczeństwo - Edukacja nr 2(12) 2017, Poznań 2017, pp. 345-360, Adam Mickiewicz University Press. ISSN 2300-0422. DOI 10.14746/kse.2017.12.17.
\end{abstract}

The following essay discusses liberal (arts) education from critical discourse analysis perspective. After a historical and philosophical introduction, three examples of liberal education discourse are discussed: 1) 'liberal arts' vs. 'Iiberal education', 2) 'liberal arts' and 'neoliberal arts' and 3) descriptions of liberal education at Wagner College in 1970 and 2013. The article concludes with a general reflection on liberal education in the current educational landscape and a tentative agenda for using the critical discourse analysis toolbox in further studies.

This essay presents the liberal education tradition as a contested site of contradictory discursive practices. After a historical introduction proposed three examples of its discursive dynamics are discussed: the divergent conceptual phrasing of the core idea, the tension between liberal education and neoliberal trends in higher education, and changes in how liberal education is understood and promoted within one institution. The conclusion addresses lessons from the three examples discussed and areas for further research inspired by critical discourse analysis. 


\section{The many faces of liberal education}

Liberal arts education, also referred to as 'liberal education', has a far reaching, complex, and well documented history in the Western culture. The intellectual ideal of education suitable for the free citizens was typically associated with the classical period in Ancient Athens (Mehrens, 2016; DeNicola, 2014). For a long time after, liberal education was less of a structured practice or a set curriculum, and more of a philosophy of education concerned with living a good life. Medieval universities were the natural site for a study of the liberal arts. But the Renaissance ideal of liberal arts - a self-rewarding exploration of the newly rediscovered classical philosophy, literature, and history - was just as important. Much later, the notion of liberal education expanded to include liberating the mind from social conventions. Cardinal John Henry Newman famously reinterpreted the liberal education offered in an Oxbridge model as an education of the whole person embodied in a broad curriculum and offered in a residential setting (Rothblatt, 1976; Newman, 1893).

In its many incarnations, liberal education included some form of character formation. Other understandings were more volatile, both those related to content (general education, broad education) and to outcomes (preparation for leadership, enhancing critical thinking) (Rothblatt, 2003). Bruce A. Kimball proposed that liberal education meant two different things in history. It started with logos, which could mean both 'speech' and 'reason'. The two terms were respectively foundational concepts of rhetoric that pursued effective cultural transmission, and dialectics that engaged with an inexhaustible search for truth. The oratorical and philosophical tradition of liberal education created the complex and often confusing history of the use of the concept (Kimball, 1995a).

American higher education structured the undergraduate degree according to the ideal of liberal education. First established in the colonial period, and later influenced by individualist, critical, democratic, and religious arguments, residential liberal arts colleges became 'distinctively American' (Koblik, Graubard, 2000). In the late $19^{\text {th }}$ century, the rise of a research ideal, specialization, and the resulting the 'academic revolution' (Jencks, Riesman, 1977), challenged traditional liberal education and forced it to adapt. But the bucolic settings of rural colleges continue to attract students seeking a transformative educational and social experience to this day. The holistic educational model (combining curricular, co-curricular, and extracurricular activities), social prestige and academic advantage of its alumni entering professional graduate programs all reinforce the continued value of liberal education. Liberal education survives by changing: both its historical forms 
and contemporary variations reflect an uneasy balance between the high minded ideal and the more sceptical public opinion.

Another tension regards its general orientation. Progressives argued that colleges should develop critical thinking, laying the foundation for active and responsible democratic citizenry (Dewey, 1929; Nussbaum, 1998). Traditionalists saw liberal education as the 'transaction between generations' and 'inherited conversation of mankind' (Oakeshott, Fuller, 2001), with the tradition of great books, core texts, and the great questions of (Western) philosophy, literature and art at the centre (Bloom, 1987). The mounting market pressures, increased social role of higher education, and the new political role of liberal education after the 'culture wars' of 1980s, led to claims that the US scene witnesses an 'overlapping pragmatic consensus' (Paris \& Kimball, 2000). ${ }^{1}$ In this approach, the liberal and the practical arts, or intrinsic and extrinsic values, blend together. Epistemic, eudemonic, civic, and holistic aspects of liberal education appear together (Harward, 2012; Harward, 2016). A liberally educated person is even portrayed as uniquely capable of solving the complex challenges of the contemporary world.

Liberal education might be an essentially contested concept (Gallie, 1956), both widely accepted as a laudable goal and variously interpreted, raising incompatible expectations. Conservatives can claim that it restores some of what the university (allegedly) used to be in the past - an institution full of humility for the wealth of cultural heritage and the scope of current knowledge. In this vision, liberal arts professors, relatively unconcerned with disciplinary careers, would encounter students with internal motivation to learn, genuinely broad interests, and ability to draw connections. On the other hand, progressives can see liberal education as a tool for social and individual improvement. The particular goals can include greater responsibility of students for their own learning, overcoming the dominant unidirectional pedagogy, developing genuine interest in applying knowledge to the current, complex, and global problems. As with other essentially contested concepts, there is no agreed way of determining which interpretation is right.

Many authors opt for a negative definition (Becker, 2014). Liberal education is non-vocational, non-professional, and not limited to a single subject, methodology or academic discipline. It is also not necessarily politically liberal. Obviously, it still does not tell us much what then a liberal education can be.

1 This definition states that 'liberal education is and should: become multicultural; elevate general education and integration, rather than specialization; promote the commonwealth and citizenship; regard all "levels" of education as belonging to a common enterprise; reconceive teaching as stimulating learning and inquiry; promote the formation of values and the practice of service; and employ assessment' (Paris, Kimball, 2000: 144). 
Outside the US, more than 180 institutions or programs globally claim that they offer liberal education (Godwin, 2015b), almost 60 in Europe. ${ }^{2}$ The sudden rise in the number of liberal arts initiatives was attributed to a shift towards the knowledge economy, a response to the massification, democratisation, and increasing influence of the US in post-Cold War world (Godwin, 2013; van der Wende, 2011; Peterson, 2012b; Godwin, Altbach, 2016). Where national higher education systems have been overhauled and harmonised - as in European Higher Education Area developed through the Bologna Process - the newly created Bachelor degree has sometimes proven more hospitable to the idea and practice of liberal education. In Europe, most liberal education developments are housed in public universities. $^{3}$

Liberal education is not only a philosophy of education, but also a social practice that highly depends on cultural and institutional context. Accordingly, the language used to describe it is both socially shaped and constitutive for the social practice (Fairclough, 1993: 134). Analysing liberal education through critical discourse analysis allows to identify 'coexisting, contrasting, and often competing discursive practices' (Fairclough, 1993: 134), identified at the level of a) mediation of particular discourse and other social elements (emergence, operationalization, foregrounding, and backgrounding), b) influence of social practices, and c) recontextualization (intertextuality and interdiscursivity) (Wodak, Fairclough, 2010). Not only 'what', but also 'how' we speak of liberal education matters; power and authority, hegemony and contestation of discursive practices all warrant careful attention. Vaguely defined, historically dynamic, and geographically dispersed discourse of liberal education lends itself particularly well to analysis of this kind.

\section{Example 1: Liberal education vs. liberal arts education}

The continued preference for 'liberal education' over 'liberal arts' reflects the influence of Cardinal John Henry Newman, whose impact on the philosophy of Anglo-Saxon higher education was comparable to Wilhelm for Humboldt's in continental Europe (Rothblatt 1997). For Newman, liberal education was the true purpose of a university, while the role of research was secondary. The cultivation of the mind, learning for its own sake, and awareness of the unity of all knowledge are

${ }^{2}$ In Poland, MISH colleges (and to some extent MISMaP colleges), as well as Collegium Artes Liberales at the University of Warsaw are primary examples. European Liberal Arts Initiative (www. liberal-arts.eu) provides a current database of European liberal arts programs.

3 The diversity of institutional models of liberal education in Europe is discussed in Kontowski, 2018. 
mixed together to turn out the 'good members of society' (DeNicola, 2014, see also Newman, 1893). In the US, the Yale Report of 1832 also used the term 'liberal education' to describe the foundation for further studies, and a desirable aim of education in college, that would be 'broad, deep, and solid' and provide students with the 'furniture of mind' (Yale College Faculty Committee, 2010 [1832]).

At the same time, the curriculum defended forcefully by Yale Faculty in the early 19th century was based on the liberal arts, at that time understood as traditional academic disciplines in opposition to the social sciences, sciences, and pre-professional programs. The common understanding of liberal (arts) education, today includes the first two, showing well that the 'liberal arts' are indeed 'the living arts' (Rothblatt, 2003). The term 'liberal arts' features in the institutional charts (as in 'college of liberal arts' that delivers undergraduate instruction at many research universities) but is less prominent in policy papers and outreach documents. The possible reason was that such the humanities were criticized since the 1980s as useless for the production of skilled professionals, effectively an expensive hobby for the upper class and the reason for the 'liberal bias' in the American academia (D’Souza. 1992; Anderson, 1992).

On the other hand, the term 'liberal education' allowed much more flexibility. It did not suggest it can only happen in a (private) liberal arts college, with a specific curriculum, cost range, and social function. Association of American Colleges and Universities, a major advocacy organisation, has adopted the 'liberal education' approach ${ }^{4}$ - and subsequently grew to the current 1400 institutions (37\% of all US higher education institutions). Liberal education no longer suggests the 'Great Books' reading lists that inflamed some of the 'culture wars' (Carnochan. 1993; Gless. Herrnstein Smith. 1992), ${ }^{5}$ but instead offers politically safe discourse of holistic student experience in any higher education institution.

The 'liberal arts' phrasing dominates in the continental Europe and in the UK (University College Deans Network 2014; European Colleges of Liberal Arts and Sciences n.d.). Exceptions (Gazette CEU, 1998; Axer, 1997; Nørgaard, 2013; Nørgaard, 2016) include authors with ties to the US liberal arts scene. An organisation promoting liberal education in Central and Eastern Europe was called 'Artes Liberales' (1996-2001). Latin provided a common ground for institutions scattered across the post-communist countries and reassured original inspiration. To refer back to artes liberales was to revisit the principles of the first universities in Europe (Zimmermann, 2013). In a context of a modern research university,

\footnotetext{
${ }^{4}$ See for example Association of American Colleges and Universities, 2012.

${ }^{5}$ For a current move towards the great books in European settings see Cohen de Lara, Drop, 2017.
} 
interdisciplinary connections and a broader curriculum offered by a liberal arts program were more attractive point of reference. A 'liberal arts' program promises students 'a better deal': they would get more and better access to university courses. 'Liberal education' would not convey this subtle meaning.

\section{Example 2: Liberal education vs. the neoliberal arts}

Some scholars link the rise of European liberal arts degrees to the Bologna Process (Van der Wende, 2011; Godwin, 2013), which introduced modular curricula, a distinction between broader undergraduate and more specialized graduate programs, and a set of tools for mobility between programs, universities, and countries. The Bologna Process emphasised both education for democratic citizenship (within the integrating European Union) and education for employability in the knowledge economy. This ambiguity can be traced throughout European liberal education in its historical and geographical diversity. Historically non-vocational liberal education narrative was by no means immune to the dominant trends affecting higher education worldwide. The last four decades witnessed the ascendancy of neoliberalism in educational theory and policy, and new public management in university administration (Hursh, 2016; Roberts, Peters, 2008; Brown, 2015; Harvey, 2005). The core assumption of neoliberalism is that of the primacy of market regulation to achieve the optimal allocation of resources, reducing governmental control over public services, and effectively reframing higher education as a private good.

The overlap between liberal education and neoliberalism was noticed only recently (Deresiewicz, 2016; Burawoy, 2016) as the values promoted by neoliberalism - free market, freedom of expression, and the free society (Hursh, 2016) - at a first glance seem theoretically compatible with liberal education. But practices differ. First, conceiving higher education in market terms fuels consumerist attitudes of the students, and thus commercialisation and commodification; yet even the most individualistic interpretation of liberal education as personal development would still consider it a public good. Secondly, in relation to public higher education, neoliberal policies assess educational programs by their market relevancy, favouring the short-term employability whereas liberal education is values the long-term goals of lifelong learning, love for learning, and personal satisfaction. Finally, in the 'neoliberal arts' approach critical thinking becomes only a tool to improve the competitive position of an institution, a researcher, or a student; liberal education engages in questioning for its own sake.

Yale-NUS in Singapore, a joint initiative of an Ivy League university and a big research university set out to establish 'liberal arts: in Asia, for the world' provides an example of this overlap. The transpacific collaboration was part of a 'global hub' 
strategy that seeks to improve the position of Singapore in the global knowledge economy without abandoning the limits its government imposes on academic freedom. While the founding president of Yale-NUS College praised 'globally aware citizens' who can be 'more innovative contributors to the economy and society' (Lewis, 2016: 49), his critics rebuked that Yale-NUS runs on a marketized notion of liberal education, an elite education used as a way of getting ahead in the global competition for talent, not as a tool for social critique (Liu, Lye, 2016). When the traditional ideal of liberal learning has been hegemonized by a neoliberalized education, a 'functionalist creativity' replaces the true spirit of the liberal arts education (Newfield, 2017).

It does not have to be this way. Competitive, pragmatist, economized values dominate higher education discourse in many Asian countries. But aside of the professional model of a (Western) research university they adopted in XIX and early XX century, original traditions of liberal or general learning could still appeal for producing well-rounded, literate, ethically aware citizens (Nussbaum, 2011; Altbach, 2016; Jung et al., 2016). In this perspective, liberal education becomes a global palimpsest: traditions and influences, ideas and power relations, internal and external discourses jointly co-create new qualities.

The ideal of liberal education was used to catalyse changes in the structure of an existing institution (Kontowski, 2016a), or establishing a radical organizational and curricular alternative (Norgaard, Hajnal, 2014). But despite the popular mantras of knowledge economy and innovation (Greenwood, 2009), the promoters of liberal education were unable to affect policies and discursive practices in higher education tout court. Both the concept and the language of liberal education remain largely unknown outside the United States - and even the typical defence mentions now there an increased job readiness of its graduates to meet the alleged challenges of tomorrow. Only a handful of selective U.S. liberal arts colleges can still emphasize the traditional cultivation of the mind. Other colleges often opt for a combination of liberal arts with STEM disciplines, pre-professional courses, and internships in attracting their 'clients' by offering them a broader set of transferable and soft skills. Almost all such arguments can be interpreted as 'neoliberal', advancing a narrow view of usefulness of university graduates, creating more developed schemes of control, expecting students to exercise entrepreneurial attitudes towards their higher education, petrifying the undemocratic organisation of universities, and finally reinforcing the privileged pathways for future cosmopolitan elite knowledge workers (Shear et al., 2015).

The high-minded resilience to privatisation and short-term educational investment agenda is both easier and harder in Europe. With the exception of the 
UK, liberal education programs do not charge tuition at levels generating considerable student debt. But the general public also expects universities to deliver specialised undergraduate degrees and remains unaware of the philosophy or 'brand' of liberal education. Medicine and law degrees start at the undergraduale level, unlike in the US, putting the high-earning, prestigious professions at odds with receiving a liberal education. Perhaps not coincidentally, there is not one great books institution in all Europe, and most liberal education programs engage with the language of $21^{\text {st }}$ century skills, employability, and global competitiveness. ${ }^{6}$ European liberal education programs negotiate with the powers and dogmas of their countries, especially if they rely on public funding. Without the culture of private philanthropy, institutional endowment, and flexible accreditation, European liberal educators are more constrained than their US counterparts. ${ }^{7}$

\section{Example 3: Old and new ways of promoting liberal arts by the same institution}

In the last three decades, Wagner College (NY, USA) redefined its mission, social composition of students, and curricular philosophy (Smith 2010; Guarasci 2006). ${ }^{8}$ Comparing the undergraduate bulletin from early 1970 s with a mission statement from 2013 allows for a reflection on the general changes in American liberal education and well as a signature development of 'practical liberal arts' at Wagner (Esser et al. 2013). How Wagner College describes liberal education to its current and prospective students?

In 1970-1971 academic year, Wagner College was primarily a commuter college located on Staten Island, delivering a typical curriculum for a liberal arts institution. The general education consisted of distribution requirements, a concentration in a chosen discipline, and electives made up roughly equal parts of the coursework. In the 1960s, foreign language, physical education, and religious

${ }^{6}$ This facet of liberal education discourse matches the following excerpt from EU Skills Agenda for Europe: 'The aim is to ensure that people develop a broad set of skills from early on in life and to make the most of Europe's human capital, which will ultimately boost employability, competitiveness and growth in Europe. Critical thinking, entrepreneurship, problem solving or digital competences are just some of the competences enshrined by the New Skills Agenda. These skills emerge today as key to allow people to develop good-quality jobs and fulfil their potential as confident, active citizens', press release, 10 June 2016, http://europa.eu/rapid/press-release_IP-16-2039_en.htm.

${ }^{7}$ Predominantly public higher education and a specialized traditional curricula can be observed in Germany, where private universities wishing to embrace some of the principles of liberal education (Kontowski, Kretz, 2017).

${ }^{8}$ For the summary of the changes, see: Guarasci, 2003; Wagner College, 2011; Kontowski, 2016 b. 
studies were dropped as requirements. The bulleting from 1970 described philosophy of general education in terms of a non-specialised part of college education. In Wagner College Bulletin from that year, the required courses were preceded by this short introduction:

Traditionally and practically, to be educated a person must acquire basic knowledge and skills. He should be aware of the spiritual aspects of life and of philosophical inquiry; he should understand the nature of himself and his fellow men; he should appreciate his historical and literary heritage; he should be acquainted with the methods of science and mathematics; and he should be able to understand and to communicate in his own and another tongue. In Wagner College every student, no matter what his major, is required to achieve at least a specified minimum level of competence in fundamental fields.

The Humanities, the Sciences, and the Social Studies should contribute to the creation of a mental equipment so diversified as to assure the graduate's understanding of the problems arising in our present day life. ${ }^{9}$

Notably, this description does not mention the concept of liberal arts or liberal education at all. Many liberal arts colleges did not refer to the liberal education philosophy in bulletins, ${ }^{10}$ which might suggest that a college and a liberal arts education were almost synonymous in the US context. Additionally, Wagner early on embraced the pre-professional studies, for example nursing, and thus the traditional language of liberal arts might have caused confusion.

The audience of this document were primarily Wagner College students of that time. Originally Lutheran, Wagner secularized long before 1970s, but in the passage religious studies were still mentioned in the first sentence, even before philosophy. Wagner admitted women since 1933, but in 1970, still addressed students using a male pronoun. The normative language of the paragraph conveys the aim and content of education as both prescribed and aspirational. A student admitted to Wagner is expected to internalize its values. Electives play a minor role, allowing students to either take more courses matching their interests or simply to receive credit for participation in the 'orchestra, choir, or band'.

9 Both excerpts come from Wagner College, 1970: 62-65.

${ }^{10}$ For example Haverford College Bulletin from as far as 1933-34 does not mention the word 'liberal' in history and description of the curriculum. Unlike Wagner, Haverford was very much dedicated to the elective principle, which was often a proxy for a stronger academic focus. While the college proposed a tentative plan of studies for each student, it also ultimately relied on the faculty advisers to 'prevent unreasonable combinations of courses' during the first two years of study. After that, a student was expected to assume more responsibility for their own education and only consult with his Major Supervisor 'whose power outside the field of major concentration is, however, merely advisory' (p. 32). I am grateful to John Esser for sharing with me this fascinating resource. 
Wagner College Mission Statement from 2013 reads differently:

Wagner College prepares students for life, as well as for careers, by emphasizing scholarship, achievement, leadership, and citizenship. Wagner offers a comprehensive educational program that is anchored in the liberal arts, experiential and co-curricular learning, interculturalism, interdisciplinary studies, and service to society, and that is cultivated by a faculty dedicated to promoting individual expression, reflective practice, and integrative learning. ${ }^{11}$

As mentioned in Wagner College Strategic Plan, the liberal arts are but one of the educational philosophies and practices. Facing the common challenges for liberal education in the US, Wagner claims to offer an attractively worded alternative - Practical Liberal Arts. I would argue that choice of 'practical' was a nod to institutional heritage and new challenges, the description evokes the word 'practically' from 1970-71 description, and provides a link between social service and the social good of Lutheran philosophy of education. On the other hand, it pre-emptively refutes the typical charge that liberal arts are impractical. Wagner positions itself as an institution with a unique vision. As a philosophy of education and as a sustainable strategy for a small college, the (traditional) liberal arts are no longer enough. ${ }^{12}$

The original 1998 'Wagner Plan: the Practical Liberal Arts: Reading, Writing and Doing' offered a more authentic, engaging language than the 2013 mission statement:

A liberal education prepares students for life as well as for careers. It opens minds by introducing students to the sweep of human imagination as well as to the disappointments of human behavior. Liberal education offers students a sense of the human imprint for both good and evil. It provides students with the analytic skills necessary for critical interpretation and for effective problem solving. In every historical epoch, liberal education is about freeing the human imagination to understand the past while visualizing future beyond the present limits of human possibilities. (Wagner College Faculty, 1998)

Without reading too much into the two internal documents, Wagner moves to more clearly describe the benefits of liberal education to end-users (students). The concepts used to describe the plan and practice seem more sophisticated in

\footnotetext{
${ }_{11}$ Accessible through: http://wagner.edu/about/leadership/strategic-plan/

${ }^{12}$ The discourse of liberal education is still very limited in the Strategic Plan. Aside from 'liberal arts' (7 times, mostly with regards to Wagner Plan for Practical Liberal Arts), the Strategic Plan mentions only 'residential liberal learning' once. Wagner Plan ('Engaged, Integrated, Transformative Learning: The Wagner Plan into the Future') at once reaffirms Wagner as a liberal arts institution and distances it from its traditional connotations.
} 
2013 than in 1997. A subtle example of promotional discourse, the 2013 document impresses students by a vision of a comprehensive curriculum and coherent educational philosophy. Wagner has moved from a more personal understanding of liberal education towards a more generic college experience, and its competitive advantage now stems from a whole combination of distinctive elements ${ }^{13}$.

\section{Liberal education and critical discourse analysis studies}

Teun Dekker recently summarised that: 'if Liberal Arts is only one thing, it is nothing' (Dirksen et al., 2017: 31) and Margarethe Hattingh clarified: 'Your liberal education is what you make of it' (Dirksen et al., 2017: 7-8). Customization and personal relevance of liberal education offer an almost inexhaustible source of perpetual renewal. Liberal education retained its promise to increase the level of personal, and sometimes social, freedom experienced in different times and regimes.

Some general principles - empowering students as learners, multidisciplinary curricula, small scale courses, the collegiate ideal - might make a liberal education an example of a 'telic' reform (from $\tau \dot{\lambda} \lambda o \varsigma$ in Greek) (Grant, Riesman, 1978). A telic reform proposes not simply alternative means to achieve preconceived aims of higher education (in the $20^{\text {th }}$ century, assuring a supply of graduates for work in the job market and small subset of future academics), but a whole different set of ends, for example personal satisfaction, social cohesion, or critical engagement with politics. In the 1970s in the US, and 1990s in Europe, liberal education was a site of an active search for educational alternative; audacious educational thinking was not only possible, but necessary. While it might no longer be the case today, it might be tomorrow.

Researchers have to face an 'elusive distinctiveness' (DeNicola, 2014) of liberal education. Critical discourse analysis has the potential uncover the hidden assumptions and power differentials structuring what first appears as unproblematic or unimportant. Some examples of the questions in liberal education research that might be productively approached from a critical discourse analysis perspective include:

- In what sense the notion of 'liberal' is used in liberal education discourse? (See: Lewis 1960)

- What is the difference between 'liberal education' and 'Bildung'? (see: Hohendahl, 2011)

${ }_{13}$ Perhaps importantly, the original Wagner Plan was drafted by one person (though amended during Faculty Meetings), whereas 2011 Mission Statement was a document drafted by a committee. 
- If the concept of 'liberal (arts) education' is confusing in Europe, why is it nevertheless continuously used?

- Why the existing research (Van der Wende, 2012; 2013; Godwin, 2013; Task Force on Higher Education and Society; \& The Task Force on Higher Education in Developing Countries, 2000; Gillespie, 2001; Peterson, 2012a), focuses almost exclusively on the macro level, rendering the meso- and the micro level invisible?

- How diverse internally is the liberal education movement? What discursive factors might limit the scope of current pluralism of the European liberal arts scene?

- What can be the role of critical theory in addressing the negative aspects of liberal education 'neoliberal master narrative'? (see: Vavrus, Pekol, 2015; Godwin 2015a)

Critical discourse analysis allows to study liberal education in diachronic and synchronic perspective. Two major streams of existing research, historical-philosophical and contemporary-institutional, are both necessary to analyse liberal education discourse as a social practice. While we might never achieve a normative consensus about what liberal education is, we can certainly map the diverse understandings associated with the model and its relation to other concepts in education. The current wave of interest in the topic provides a promising starting point.

\section{Acknowledgements}

This work has been supported by Fulbright Junior Advanced Research Award 2016-17, that made my research stay at Wagner College possible. I would like to thank Sarah Donovan, John Esser, Richard Guarasci, and Lily McNair as well as many other colleagues at Wagner for the opportunity to discuss the practice of liberal education at this institution. I am also grateful to Jakob Dirksen, Nicholas Farnham, Davydd Greenwood, Tim Hoff, Dina Khapaeva, Julie J. Kidd, David Kretz, Nikolay Koposov, Karolina Mikołajewska-Zając, Thomas Norgaard, Helena Ostrowicka, Sheldon Rothblatt, Krystian Szadkowski, and Susan Wright for the conversations on liberal education during my stay in the US.

\section{References}

Altbach P.G. (2016). The many traditions of liberal arts - and their global relevance. "International Higher Education" 84, pp. 21-23.

Anderson M. (1992). Impostors in the Temple. American Intellectuals Are Destroying Our Universities and Cheating Our Students of Their Future. New York. 
Association of American Colleges and Universities. (2012). What is a 21st Century Liberal Education? http://www.aacu.org/leap/What_is_liberal_education.cfm.

Axer J. (1997). What is liberal education? Can it support both freedom and equality? Is it for everybody? "Kritika a Kontext" 4, pp. 116-118.

Becker J. (2014). What a liberal arts education is... and is not (2003/2014). "Smolny College", pp. 1-13. http://artesliberales.spbu.ru/about-en/liberal.

Bloom A. (1987). The Closing of the American Mind: How Higher Education Has Failed Democracy and Impoverished the Souls of Today's Students. New York.

Brown W. (2015). Undoing the Demos: Neoliberalism's Stealth Revolution. London.

Burawoy M. (2016). The neoliberal university: ascent of the spiralists. "Critical Sociology" 42(7-8), pp. 941-942. http://crs.sagepub.com/cgi/doi/10.1177/0896920516671296.

Carnochan W.B. (1993). The Battleground of the Curriculum. Liberal Education and American Experience. Stanford.

Cohen de Lara E., Drop H. (eds.). (2017). Back to the Core: Rethinking the Core Texts in Liberal Arts \& Sciences Education in Europe. Wilmington.

D'Souza D. (1992). Illiberal Education. The Politics of Race and Sex on Campus. New York.

DeNicola D.R. (2014). Liberal education (an overview). [In:] D.C. Philips (ed.). Encyclopedia of Educational Theory and Philosophy. Thousand Oaks, pp. 475-478.

Deresiewicz W. (2015). The neoliberal arts. "Harper's Magazine", Sept.

Dewey J. (1929). Democracy and Education; An Introduction to the Philosophy of Education. New York.

Dirksen J.T.V., Kontowski D., Kretz, D. (eds.). (2017). What Is Liberal Education and What Could It Be? European Students On Their Liberal Arts Education.

Esser J.P., McNair L.D., Guarasci R. (2013). Staying alive with the Wagner plan: how to keep a new first-year program thriving fifteeen years out. [In:] J.L. DeVitis (ed.). The College Curriculum: A Reader. New York, Delphi. http://liberal-arts.eu/ebook/.

European Colleges of Liberal Arts and Sciences, ECOLAS. http://www.ecolas.eu/, accessed: November 11, 2015].

Fairclough N. (1993). Critical discourse analysis and the marketization of public discourse: the universities. "Discourse \& Society" 4(2), pp. 133-168.

Gallie W.B. (1956). Essentially contested concepts. "Proceedings of the Aristotelian Society" 56, pp. 167-198.

Gazette CEU (1998). Statement on liberal education in Eastern Europe. "Gazette. The Chronicle of Central European University" 8(2), p. 7.

Gillespie S. (2001). Opening minds: the international liberal education movement. "World Policy Journal" Winter, pp. 79-89.

Gless D., Herrnstein Smith B. (eds.). (1992). The Politics of Liberal Education. Durham and London.

Godwin K.A. (2013). The Global Emergence of Liberal Education: A Comparative and Exploratory Study. Boston.

Godwin K.A., (2015a). The counter narrative: critical analysis of liberal education in global context. 'New Global Studies' 9(3), pp. 223-244. http://www.degruyter.com/view/j/ngs.2015.9.issue-3/ ngs-2015-0033/ngs-2015-0033.xml.

Godwin K.A. (2015b). The worldwide emergence of liberal education. 'International Higher Education’ (79), pp. 2-4. http://ejournals.bc.edu/ojs/index.php/ihe/article/view/5835/5199. 
Godwin K.A., Altbach P.G. (2016). A historical and global perspective on liberal arts education: what was, what is, and what will be. "International Journal of Chinese Education" 5, pp. 5-22.

Grant G., Riesman D. (1978). The Perpetual Dream. Reform and Experiment in the American College. Chicago and London.

Greenwood D.J. (2009). Are research universities knowledge-intensive learning organizations? [In:] J.K.D. Jemielniak (ed.). Handbook of Research on Knowledge-Intensive Organizations. Hershey and New York, pp. 1-18.

Guarasci R. (2003). The Wagner plan for the practical liberal arts: deep learning and reflective practice. [In:] Integrating Learning Communities with Service-Learning. Olympia, WA, pp. 23-29. http:// evergreen.edu/washingtoncenter/docs/monographs/servicelearning/servicelearningch4.pdf.

Guarasci R. (2006). On the Challenge of Becoming the Good College. 'Liberal Education' 92(1), pp. 2-9. http://aacu-secure.nisgroup.com/liberaleducation/le-wi06/documents/Guarasci_LE-WI06pdf.pdf.

Harvey D. (2005). A Brief History of Neoliberalism, Oxford.

Harward D.W. (2012). Transforming Undergraduate Education: Theory That Compels, and Practices That Succeed. Lanham, Md.

Harward D.W. (2016). Well-being and Higher Education: a Strategy for Change and the Realization of Education's Greater Purposes. Washington, DC.

Hohendahl P.U. (2011). Humboldt revisited: liberal education, university reform, and the opposition to the neoliberal university. "New German Critique" 38(2 113), pp. 159-196.

Hursh D. (2016). Neoliberalism and education policy. [In:] Encyclopedia of Educational Philosophy and Theory. Singapore, pp. 1-6. http://link.springer.com/10.1007/978-981-287-532-7_158-1.

Jencks C., Riesman D. (1977). The Academic Revolution. Garden City, N.Y.

Jung I., Nishimura M., Sasao T. (2016). Liberal Arts Education and Colleges in East Asia: Possibilities and Challenges in The Global Age. Singapore.

Kimball B.A. (1995a). Orators \& Philosophers: A History of the Idea of Liberal Education. New York.

Kimball B.A. (1995b). Toward pragmatic liberal education. [In:] R. Orrill (ed.). The Condition of American Liberal Education. Pragmatism and a Changing Tradition. New York, pp. 1-125.

Koblik S., Graubard S.R. (2000). Foreword. [In:] S. Koblik, S.R. Graubard (eds.). Distinctively American. The Residential Liberal Arts Colleges. New Brunswick and London, pp. XV-XVI.

Kontowski D. (2016a). On the verge of liberal arts education: the case of MISH in Poland. "Working Papers in Higher Education Studies” 2(1), pp. 58-94. http://www.wphes-journal.eu/index.php/ wphes/article/view/18.

Kontowski D. (2016b). The Paradox of 'practical liberal arts'. lessons from the Wagner College Case for liberal (arts) education in Eastern Europe. "Educational Studies" 3(3), pp. 80-109. https://vo.hse. $\mathrm{ru} / \mathrm{en} / 2016--3 / 191152255 . \mathrm{html}$.

Kontowski D. (forthcoming 2018). Emerging alternative designs for higher education: Liberal arts initiatives in Europe. [In:] S. Wright, R.W.B. Lund (eds.). University Futures. Critical Perspectives, Alternative Designs. Oxford.

Kontowski D., Kretz D. (2017). Liberal education under financial pressure: the case of private German universities. [In:] R. Deem, H. Eggins (eds.). The University as a Critical Institution?. RotterdamBoston-Taipei.

Lewis C.S. (1960). Free. [In:] Studies in Words. Cambridge and New York, pp. 111-132.

Lewis P. (2016). In Asia, for the world: liberal education and innovation. [In:] Experiences in Liberal Arts and Science Education from America, Europe, and Asia. New York, pp. 47-60. http://link. springer.com/10.1057/978-1-349-94892-5_4. 
Liu P., Lye C. (2016). Liberal arts for Asians. "Interventions" 18(4), pp. 573-587. http://www.tandfonline.com/doi/full/10.1080/1369801X.2015.1126194.

Mehrens P. (2016). Liberal arts education. [In:] M.A. Peters (ed.). Encyclopedia of Educational Philosophy and Theory. Singapore: Springer Singapore, pp. 1-5. Available at: http://link.springer. com/10.1007/978-981-287-532-7_483-1.

Newfield, C., 2017. Arts and humanities education as neo-liberalism comes unglued. 'Parse Journal' 5, pp. 34-45.

Newman J.H. (1893). The Idea of a University, Defined and Illustrated (new edition). London.

Nørgaard T. (2013). Liberal education in the Erasmus Programme. "Oxford Studies in Comparative Education" 23(2), pp. 99-118.

Nørgaard T. (2016). Friendship, conversation \& liberal education. [In:] K. Marciniak, E. Olechowska (eds.). De Amicitia. Transdisciplinary Studies in Friendship, pp. 255-266. http://www.al.uw.edu. $\mathrm{pl} / \mathrm{amicitia}$.

Nørgaard T., Hajnal P. (2014). Value studies and democratic citizenship. [In:] J.N. Reich (ed.). Civic Engagement, Civic Development, and Higher Education. New Perspectives on Transformational Learning. Washington, D.C., pp. 41-46.

Nussbaum M.C. (1998). Cultivating Humanity: A Classical Defense of Reform in Liberal Education. Cambridge, Mass.

Nussbaum M.C. (2011). Democracy, education, and the liberal arts: Two Asian models. "UC Davis Law Review" 44(735), pp. 735-772. http://heinonlinebackup.com/hol-cgi-bin/get_pdf. cgi?handle=hein.journals/davlr44\&section $=25$.

Oakeshott M., Fuller T. (2001). The Voice of Liberal Learning. Indianapolis, Ind.

Paris D.C., Kimball, B.A. (2000). Liberal education: An overlapping pragmatic consensus. "Journal of Curriculum Studies" 32(2), pp. 143-158. http://www.tandfonline.com/doi/abs/10. 1080/002202700182682.

Peterson P.M. (2012a). A global framework. liberal education in the undergraduate curriculum. [In:] P.M. Peterson (ed.). Confronting Challenges to the Liberal Arts Curriculum: Perspectives of Developing and Transitional Countries. New York and Oxon, pp. 1-23.

Peterson P.M. (2012b.). Confronting Challenges to the Liberal Arts Curriculum: Perspectives of Developing and Transitional Countries. New York.

Roberts P., Peters M. (2008). Neoliberalism, Higher Education and Research. Rotterdam.

Rothblatt S. (1997). The idea of the idea of a university and its antithesis. [In:] Modern University and its Discontents. Cambridge, pp. 1-49.

Rothblatt S. (2003). The Living Arts: Comparative and Historical Reflections on Liberal Education, Washington, D.C.

Rothblatt S. (1976). Tradition and Change in English Liberal Education: An Essay in History and Culture. London.

Shear B.W., Hyatt S.B., Wright S. (2015). Learning Under Neoliberalism: Ethnographies of Governance in Higher Education. New York.

Smith N.R. (2010). From Bottom to Top Tier in a Decade The Wagner College Turnaround Years. Bloomington.

Task Force on Higher Education and Society; \& The Task Force on Higher Education in Developing Countries (2000). Higher Education in Developing Countries: Peril and Promise. Washington, DC.

University College Deans Network (2014). Statement on the Role, Characteristics, and Cooperation of Liberal Arts and Sciences Colleges in the Netherlands. University Colleges Deans of the Netherlands. https://www.universitycolleges.info/. 
Van der Wende M.C. (2012). Trends Towards Global Excellence In Undergraduate Education: Taking the Liberal Arts Experience Into the 21st Century. Berkeley.

Van der Wende M.C. (2013). An excellence initiative in liberal arts and science education: The case of Amsterdam University College. [In:] Q. Wang, Y. Cheng, \& N.C. Liu (eds.). Building World-Class Universities. Different Approaches to a Common Goal. Shanghai, pp. 89-102.

Van der Wende M.C. (2011). The Emergence of Liberal Arts and Sciences Education in Europe: A Comparative Perspective. 'Higher Education Policy' 24, pp. 233-253.

Vavrus F., Pekol A. (2015). Critical Internationalization: Moving from Theory to Practice. "FIRE: Forum for International Research in Education” 2(2), pp. 5-21. http://preserve.lehigh.edu/firfe/ vol2/iss $2 / 2$.

Wagner College. (1970). Wagner Bulletin 1970-71. Wagner College.

Wagner College. (2011). Engaged, integrated, transformative learning: the Wagner plan into the future. Wagner Strategic Plan. https://wagner.edu/about/leadership/strategic-plan/.

Wagner College Faculty (1998). The Wagner Plan. The Practical Liberal Arts: Reading, Writing \& Doing. Wagner Colleges.

Wodak, R., Fairclough N. (2010). Recontextualizing European higher education policies: the cases of Austria and Romania. "Critical Discourse Studies" 7(1), pp. 19-40. http://www.tandfonline. com/doi/abs/10.1080/17405900903453922.

Yale College Faculty Committee (2010). Reports on the Course of Instruction in Yale College. [In:] D.B. Potts (ed.). Liberal Education for a Land of Colleges: Yale's 'Reports' of 1828. New York, pp. 84-155.

Zimmermann B. (2013). Septem. Von artes liberales zu liberal arts. Freiburg im Breisgau. 